\title{
First report of sheep naturally infected with Trypanosoma sp. in Ecuador
}

\section{Roberto Darwin Coello-Peralta ${ }^{* *}$ Nelson Catito Cabrera Solórzano ${ }^{2}$ Kevin Andrés Ruiz Peñafiel ${ }^{1}$ María de Lourdes Salazar Mazamba ${ }^{1}$ Enrique Omar Reyes Echeverria ${ }^{1}$}

${ }^{1}$ Faculty of Veterinary Medicine and Zootechnics (FMVZ), University of Guayaquil (UG), 090112, Guayaquil, Ecuador. E-mail: roberto. coellope@ug.edu.ec. "Corresponding author.

${ }^{2}$ Department of Animal Diagnostics, Phyto and Zoosanitary Regulation and Control Agency (AGROCALIDAD), Guayaquil, Ecuador.

ABSTRACT: The prevalence of trypanosomiasis in sheep is of worldwide concern. It is a hemoparasitic disease caused by the protozoan Trypanosoma (T) spp., andthe biological cycle of transmission involves susceptible hosts and certain hematophagous flies, such as Tabanids and Stomoxys. The objective of this study was to determine the presence of Trypanosomasp. in sheep (Ovisaries). Through an applied, descriptive-prospective-cross-sectional qualitative study conducted between October 1, 2018, and January 29, 2019, blood samples extracted from the jugular vein were analyzed by the blood smear method using 2 Romanowsky staining techniques (Giemsa and Diff-Quick). Animals studied were between ages of 3 and 10 years, coming from 3 farms in the city of Colimes (Ecuador). Of 100 sampled and processed animals, 2 (2\%) were positive for Trypanosoma sp., constituting the first report of this hemoparasite in sheep in Ecuador, and 1 case of Babesia spp. (1\%) and 4 cases of Anaplasma marginale (4\%) were also identified. However, none of these cases presented symptomatology of any hemotropicparasitic disease. Subsequently, the positive animals were dewormed.The presence of these parasites wasconfirmedat the study site and,thus, could become a serious animal health problem.

Key words: Ovisaries, Trypanosomiasis, Romanowsky staining, Trypanosoma sp.

Primeiro relato de ovinos naturalmente infectados com Trypanosoma sp. no Equador

RESUMO: A tripanossomiase em ovelhas é uma hemoparasitose globalmente prevalente causada pelo protozoário chamado Trypanosoma (T) sp. O ciclo de vida de transmissão envolve hospedeiros suscetiveis e alguns dípteros hematófagos como Tabanids e Stomoxys. O objetivo destetrabalho foi determinar a presença de Trypanosoma sp. em ovelhas (Ovisaries). Através de um estudo aplicado, com abordagem qualitativa, do tipo descritivo prospectivo-transversal, realizado entre o dia primeiro-de outubro de 2018 e 29 de janeiro de 2019, foram analisadas amostras de sangue extraídas da veía jugular pelo método do esfregaço de sangue, utilizando duas técnicas de coloração Romanowski (Giensa e Diff-Quick). Os animais estudados tinham entre três e dez anos de idade, de três-fazendas no municipio de Colimes (Equador). Dos 100 animais amostrados e processados, dois casos (2\%) foram positivos para Trypanosoma sp., constituindo o primeiro relato deste hemoparasita em ovelhas no Equador. Além disso, um caso de Babesia sp. (1\%) e-quatro casos de Anaplasma marginale (4\%); entretanto, em nenhum desses casos houve sintomas de qualquer doença hemotropicoparasitária. Animais positivos foram posteriormente desparasitados. A presença desses parasitas foi confirmada no local do estudo e, portanto, pode se tornar um sério problema de saúde animal.

Palavras-chave: Ovisaries, Trypanosomiasis, Romanowski mancha, Trypanosoma sp.

\section{INTRODUCTION}

The domestic sheep (Ovisaries) in Ecuador is an animal $90 \%$ adapted to extreme climate and management conditions, and its rearing is underexploited in the llanuras (plains) and sub-plains of high elevation mountains that in some cases are abandoned and others poorly used. The production of sheep is generally in the hands of marginal farmers, who, through them, obtain meat, wool, milk, skins, natural fertilizers and other products that provide subsistence for many Ecuadorian families (ANCO, 2019).
However, there is little information about the risk of animals contracting hemoparasitic diseases, such as trypanosomiasis, through domestic sheep breeding, representing a serious problem for the development of the livestock industry in Africa, Asia and Latin America (PARRA-GIMENEZ \& REYNA-BELLO, 2019).

Trypanosomiasis in sheep is caused by unicellular flagellar protozoa belonging to the family Trypanosomatids and the genus Trypanosoma; the latter includes many species that cause diseases in domestic and wild animals as well as humans (AREGAWI et al., 2019). 
There are 3 species of trypanosomes of veterinary importance in South America: Trypanosoma evansi, the causative agent of surra, transmitted mechanically by blood-sucking insects such as tabanids; T. vivax, also mechanically transmitted by some hematophagous diptera such as Tabanids and/or Stomoxys; and T. equiperdum, a tissue parasite adapted for sexual transmission and the causative agent of dourine, a distinctive disease affecting only equines (PARRA-GIMENEZ \& REYNA-BELLO, 2019).

Although Trypanosoma evansi preferentially affects horses and camels, it can also affect donkeys, dogs, cats, cows and buffalo (DESQUESNES et al., 2013), but in sheep, experimental infections have resulted in a chronic and often cryptic disease, with low parasitemia and, in some cases, self-healing (ONAH et al., 1996; AUDU et al., 1999).

Trypanosoma vivax causes a critical and often deadly disease in ruminants such as cattle, buffalo, sheep and goats. Among clinical signs, fever, wasting, anemia, anorexia, immunosuppression, thrombocytopenia, formation of microthrombi, and hemorrhage suggestive of disseminated intravascular coagulation have been reported (PARRAGIMENEZ \& REYNA-BELLO, 2019;MAGEZ \& RADWANSKA, 2014).

Importantly, in the world in recent years, there has been little information on trypanosomiasis in sheep; therefore, there is little literature on the subject. In Ecuador, cases of trypanosomiasis in sheep have not been identified, but in 2017, the first report of T. vivax in bovines was described (REYNA BELLO, 2017).

The objective of this preliminary study was to determine the presence of Trypanosoma sp. in sheep from a rural area on the Ecuadorian coast.

\section{MATERIALS AND METHODS}

\section{Study area and time period}

This study was conducted on 3 farms in the rural sector of the city of Colimes, located in the northern part of the province of Guayas, on the Ecuadorian coast. Its geographical coordinates are $01^{\circ} 32^{\prime}$ '43.9" South and $80^{\circ} 01^{\prime}$ '00" West. The city has 25,167inhabitants, with 6,352 households, and is divided into an urban zone and a rural zone, with $77.7 \%$ of the population residing in the rural zone.

The country has an altitudinal range of 32-232 meters above sea level (m.a.s.l) and a humid-tropical climate, with marked differences between winter (rainy) and summer (dry), with temperatures ranging from 25 to $26^{\circ} \mathrm{C}$. An applied, qualitative, descriptive-prospective-cross-sectional study was conducted between November 1, 2018, and June 30, 2019.

\section{Sampling}

Before obtaining samples, the research protocol was analyzed and approved by the Research Coordination of the Faculty of Veterinary Medicine of the University of Guayaquil, following the protocols of authors such as (AL-KHALIFA et al., 2009; ADEJINMI et al., 2010; SEBELE et al., 2015). After approval, the inhabitants of the studied farms were informed about the importance of conducting the research and about the risk of the disease in the infected animals. Then, informed consent was requested from the domestic sheep owners, and with prior acceptance, non probabilistic directed sampling was performed, in which blood samples were taken directly from the jugular vein of 100 sheep from 3 farms in the rural zone (Entrance to Colimes, Loss Enclosure and The Guabito) of the city of Colimes. The following sampling procedure was performed. The animal was restrained, excess hair was shaved, complete antisepsis was performed on the sample extraction area, and pressure was exerted on the vacutainer tube containing EDTA (ethylenediaminetetraacetic acid) anticoagulant. Approximately $4 \mathrm{ml}$ of blood was vacuum-extracted and then transported in a cooler, maintained at temperature between 4 and $8^{\circ} \mathrm{C}$ using cooling gel, to the Laboratory of Animal Diagnostics of the Phytosanitary and Zoosanitary Regulation and Control Agency (AGROCALIDAD) of Guayaquil, where the samples obtained were analyzed.

Additionally, in the present study, the following were recorded: symptoms, body condition, temperature and conjunctiva status. Regarding body condition, the following clinical parameters were analyzed: state $1=$ extremely low weight animal; state 2 = low weight animal; state 3 = animal in good condition; state $4=$ overweight animal; and stage $5=$ obese animal (ROMERO, 2015).

The body temperature of the sheep studied was classified using the following parameters: $>40{ }^{\circ} \mathrm{C}$ = fever-pyrexia (hyperthermia); $39-40{ }^{\circ} \mathrm{C}=$ normal; 37-39 ${ }^{\circ} \mathrm{C}=$ moderate hypothermia; and $\angle 37{ }^{\circ} \mathrm{C}=$ severe hypothermia (MENDOZA et al., 2013).

Conjunctiva status was determined using criteria published by MENDOZA et al. (2010): status $1=$ optimal; status $2=$ normal, acceptable; status $3=$ intermediate; status $4=$ dangerous; and status $5=$ fatal. 
Laboratory analysis

Blood smears were performed, with

Giemsa and Diff-Quick staining separately, as described by AL-KHALIFA et al. (2009). Samples were analyzed under a microscope $(100 \times$ objective $)$ using immersion oil to identify Trypanosoma sp.

\section{RESULTS}

Of the 100 samples processed by the 2 methods, 2 animals were positive for Trypanosoma sp., resulting in a prevalence of $2 \%$.

During the study, the following were also observed: 1 animal positive for Babesia sp. (1\%) and 4 animals positive for Anaplasma marginale (4\%) (Table 1). The infected animals provenance of two farms which are Entrance to Colimes and Loss Enclosure, with a distance of $30 \mathrm{~km}$ between them; also, only one sheep was introduced, because it was bought in the Province of Manabí, the others were from the sector studied, likewise, the presence of vectors was observed in all farms.

Also, results indicated Hemoparasitic coinfection of Trypanosoma sp. and Anaplasma marginale in sample-039 and of Babesia sp. and Anaplasma marginale in sample-047 (Table 1).

Animals that were positive did not present any symptomatology of hemoparasitism during the study period but showed slight anemia through a biochemical test; likewise, all presented body state 3 (good condition), a normal temperature of $39^{\circ} \mathrm{C}$, and conjunctiva status 1 (normal) (MENDOZA et al., 2013) (Table 2).

Deworming with diminazene aceturate was performed on all positive animals intramuscularly with a single dose of $3.5 \mathrm{mg} / \mathrm{kg}$ of weight (equivalent to $1 \mathrm{ml} / 20 \mathrm{~kg}$ of weight), besides vitamins and immune support. Additionally, periodic evaluations were conducted for 2 months to rule out the presence of any kind of hemoparasite (DEMESSIE \& DERSO, 2015).

\section{DISCUSSION}

In the present study, the presence of Trypanosoma sp. was identified in 2animals (2\%), and in Paraguay, 1 case has been reported (TOMASSI et al., 2018). The prevalence, however, is below that reported in countries such as Iraq (3.3\%) (HASAN, 2012), Nigeria (7.4\%) (DANIEL et al., 1994), Venezuela (9.75-62.3\%) (MORA \& CASTRO, 2015), Brazil (approximately 25\%) (BATISTA et al., 2009), Kenya (25.3\%)(NG'AYO et al., 2005), Colombia (46.2\%) (AVILA et al., 2013) and Nicaragua (3747\%) (MORA \& CASTRO, 2015). In addition, DESQUESNES et al. (2013) claimed that T. evansi was observed for the first time in Paraguay in 1847 and that $T$. vivax was described nearby Pantanal region of Brazil(CAMPIGOTTO et al., 2015).

Also, natural infections with $T$. evansi in sheep have been reported in countries such as: Egypt, Ethiopia, Sudan, India, Guyana and Spain. In these mentioned, an accumulated prevalence between 1 to $27 \%$ is reported (AREGAWI, 2019).

In this study, the presence of Trypanosoma sp. was identified in sheep from Ecuador, reporting a low prevalence $(2 \%)$, presumably at early detection of the parasite and a limited interaction of transmission between parasites - hosts - and environment.

Additionally, in this study, 1 animal was positive for Babesia sp. (1\%), and 4 animals were positive for Anaplasma marginale (4\%). ALKHALIFA et al. (2009), in a study conducted in sheep from Saudi Arabia, reported Anaplasma ovis in $\%$ of the animals studied and Babesia sp. in 4\%; SEBELE et al. (2015), in a study conducted in Ethiopia, reported the presence of Anaplasma ovis in 1.8\% of the animals studied; ADEJINMI et al. (2004), in a study conducted in Nigeria, reported a prevalence

Table 1 - Positive samples and type of hemoparasites identified during the study.

\begin{tabular}{|c|c|c|c|}
\hline Positive sample & Giemsa & Diff-Quick & Hemoparasites identified \\
\hline Sample-035 & Negative & Positive & Trypanosoma sp. \\
\hline Sample-039 & Positive & Positive & Trypanosoma sp. and Anaplasma marginale \\
\hline Sample-047 & Positive & Positive & Babesia sp. and Anaplasma marginale \\
\hline Sample-073 & Positive & Positive & Anaplasma marginale \\
\hline Sample-075 & Positive & Positive & Anaplasma marginale \\
\hline
\end{tabular}

Ciência Rural, v.51, n.1, 2021. 
Table 2 - Relationship between positive cases and symptoms, body condition, temperature and conjunctiva status.

\begin{tabular}{lcccc}
\hline Positive cases & Symptoms & Body condition & Temperature & Conjunctiva status \\
\hline Sample-035 & NO & 3 & 39.0 & Normal \\
Sample-039 & NO & 3 & 39.0 & Normal \\
Sample-047 & NO & 3 & 39.0 & Normal \\
Sample-073 & NO & 3 & 39.0 & Normal \\
Sample-075 & NO & 3 & 39.0 & Normal \\
\hline
\end{tabular}

of $1.9 \%$ for Babesia sp. and $12.2 \%$ for Anaplasma sp.; and MOHAMMED et al. (2018), in a study conducted in Sudan, detected Babesia sp. (46.70\%) and Anaplasma sp. (19.82\%).

Furthermore, this study detected hemoparasite coinfection with Trypanosoma sp. (2\%) and Anaplasma marginale (4\%), but there is little information on the prevalence of this coinfection., and withrespect a Babesia sp. (1\%) and Anaplasma marginale (4\%) found, AL-KHALIFA et al. (2009) described Babesia sp. (4\%) and Anaplasma ovis (2\%); ADEJINMI et al. (2004) determined Babesia sp. $(1,9 \%)$ and Anaplasma ovis $(12,2 \%)$ and RENNEKER et al. (2013) described Babesia sp. (1,5\%) and Anaplasma ovis (62,6\%)

It is important to highlight that all the animals positive for hemoparasites were asymptomatic, but with the presence of mild anemia; unlike those reported by IKEDE (1979), LOSOS \& IKEDE (1972), MORA \& CASTRO et al. (2015) and TOMASSI et al. (2018), where the following symptoms are described in infected sheep: fever, loss of appetite, weakness, loss of mass, progressive anemia, lymphadenopathy, pale oral and conjunctival mucosa, bruising in the inguinal region and mild bilateral serous nasal discharge. Likewise, bloody diarrhea, enlarged spleen, respiratory dyspnea, decreased pulse rate, difficulty opening the mouth and, in severe cases, neurological and eye damage, hypothermia and death usually appear.

In South America, the disease caused by T. vivax in ruminants is predominantly chronic, with clinical manifestations related to progressive wasting, anemia, and a variable increase in lymph nodes, with death observed only occasionally (MORA \& CASTRO, 2015).The presence of signs and symptoms of disease in the sheep studied would presumably be due to the patent (asymptomatic) state of the infected host.

This study indicated that hemotropic parasites are present in the blood of sheep in the cityof Colimes, which is influenced by climatic characteristics that favor the presence of vectors for the transmission of this parasitosis, but there is a potential risk of cases of the disease occurring in surrounding areas due to the presumption of parasitic circulation in infected vectors.

With these events exposed, we suggested that the blood samples from the animals be subjected to confirmatory tests (PCR) to determine the species of Trypanosoma; as described by N'DJETCHI (2017) in Africa. These data, in addition to enriching the research, are valuable information for local health authorities and the OIE.

\section{CONCLUSIONS}

In samples taken from domestic sheep from 3 farms in the rural area of the city of Colimes in Ecuador, Trypanosoma sp. (in 2\% of the samples) and other hemotropic parasites (Anaplasma maginale and Babesia sp.) (in $5 \%$ of the samples) were identified through blood smears using 2 staining techniques, Giemsa and Diff-Quick, implying a potential risk of hemoparasites being present at the sites studied.This research was is important because it showed that the detected parasites are present in the country and can cause an epizootic. Furthermore, this information is relevant to epidemiological surveillance systems and animal health.

Moreover, it is important to improve the dissemination and promotion of educational programs on these parasites and to establish effective control measures to reduce the infectious forms of parasites in animals.

Notably, coinfection with 2 hemoparasites was detected in the samples obtained. In addition, all the animals investigated did not present symptoms of hemoparasitic disease and had a good body condition, normal temperature and good conjunctiva status.

\section{ACKNOWLEDGMENTS}

Authors gratefully thank to MSc. Allan Sotomayor Marin ( $\dagger$ ) for allowing us to work in the Animal Diagnostic 
Laboratory of the Agency for Regulation and Control of Phytosanitary and Zoosanitary (Agrocalidad) of Guayaquil Ecuador, to the sheep owners who gave their consent to use their animals for the study; and the Research Coordination of the Faculty of Veterinary Medicine and Zootechnics of the University of Guayaquil, for having reviewed the research methodology.

\section{DECLARATION OF CONFLICTS OF INTERESTS}

The authors covered the full funding of the research, therefore, there is no conflict of interest with any financial organization regarding the material discussed in the manuscript. In addition, those mentioned also contributed to the manuscript.

\section{REFERENCES}

ADEJINMI, J., et al. Studies on the blood parasites of sheep in Ibadan, Nigeria. African Journal of Biomedical Research. v.7, p.1975-1977, 2010. Available from: <https://doi.org/10.4314/ ajbr.v7i1.54066>. Accessed: Feb. 04, 2020. doi: 10.4314/ajbr. v7i1.54066.

AL-KHALIFA, M.S., et al. Blood parasites of livestock in certain Regions in Saudi Arabia. Saudi Journal of Biological Sciences. v.16, p.63-67, 2009. Available from: <https://doi.org/10.1016/j. sjbs.2009.10.002>. Accessed: Feb. 04, 2020. doi: 10.1016/j. sjbs.2009.10.002.

ANCO. Nacional Association of Sheep of Ecuador. The Sheep Industry in Ecuador. 2019. Available from: $<\mathrm{http}: / / \mathrm{www}$.geocities. ws/ancoec/industry.html>. Accessed: Feb. 04, 2020.

AREGAWI, W.G., et al. (2019). Systematic review and metaanalysis on the global distribution, host range, and prevalence of Trypanosoma evansi. Parasites \& Vectors. v12, 2019. Available from: <https://doi.org/10.1186/s13071-019-3311-4>. Accessed: Feb. 05, 2020. doi: 10.1186/s13071-019-3311-4.

AUDU, P. A., et al. Studies of infectivity and pathogenicity of an isolate of Trypanosoma evansi in Yankasa sheep. Veterinary Parasitology, v86, p.185-190. 1999. Available from: <https://doi. org/10.1016/S0304-4017(99)00141-7>. Accessed: Feb. 05, 2020. doi: 10.1016/S0304-4017(99)00141-7.

AVILA PULGARIN, L.S., et al. Hemoparasite infection in goats and sheep at five municipalities in north and northeastern Antioquia (Colombia). Revista CES Medicina Veterinararia y Zootecnia. v.8, p.14-24, 2013. Available from: <https://dialnet.unirioja.es/ servlet $/$ articulo? codigo $=4424392>$. Accessed: Jan. 05, 2020. doi: $10.21615 / 2830$.

BATISTA, J.S., et al. Infection by Trypanosoma vivax in goats and sheep in the Brazilian semiarid region: From acute disease outbreak to chronic cryptic infection. Veterinary Parasitology. v.165, p.131-35, 2009. Available from: <https://doi.org/10.1016/j. vetpar.2009.07.005>. Accessed: Jan. 05, 2020. doi: 10.1186/ s13071-015-1169-7.

CAMPIGOTTO, G., et al. Experimental infection by Trypanosoma evansi in sheep: Occurrence of transplacental transmission and mice infection by parasite present in the colostrum and milk of infected ewes. Veterinary Parasitology. v212, p.123-29, 2015. Available from: <https://doi.org/10.1016/j.vetpar.2015.07.007>. Accessed: Jan. 05, 2020. doi: 10.1016/j.vetpar.2015.07.007.
DANIEL, A.D., et al. Prevalence of trypanosomiasis in sheep and goats in a region of northern Nigeria. Revue d'élevage et de Médecine Vétérinaire Des Pays Tropicaux. v.47, p.295-97, 1994. Available from: <https://doi.org/10.19182/remvt.9091>. Accessed: Jan. 05, 2020.doi: 10.19182/remvt.9091.

DEMESSIE, Y.; DERSO, S. Tick borne hemoparasitic diseases of ruminants: a review. Advances in Biological Research. v.9, p.210-24, 2015. Available from: <https://doi.org/10.5829/idosi. abr.2015.9.4.9516>. Accessed: Jan. 05, 2020. doi: 10.5829/idosi. abr.2015.9.4.9516.

DESQUESNES, M., et al. Trypanosoma evansi and surra: A review and perspectives on origin, history, distribution, taxonomy, morphology, hosts, and pathogenic effects. BioMed Research International. 2013. Available from: $<$ https://doi. org/10.1155/2013/194176>. Accessed: Jan. 05, 2020. doi: $10.1155 / 2013 / 194176$.

HASAN, M.H. Diagnosis of some blood parasites in cattle and sheep in Mosul, Iraq. Iraqi Journal of Veterinary Sciences. v.26, p.57-61, 2012. Available from: <https://pdfs.semanticscholar.org/ 4341/4c675de70d191cfaa4f3a09d07083c889edd.pdf > . Accessed: Jan. 05, 2020. doi: 10.33899/ijvs.2009.5692.

IKEDE, B.O. Genital lesions in experimental in chronic Trypanosoma congolense infection in rams. Researchin Veterinary Science. v.26, p.145-151, 1979. Available from: <https://www. researchgate.net/publication/22874101_Genital_lesions_in experimental_chronic_Trypanosoma_brucei_infection_in_rams $>$. Accessed: Jan. 05, 2020. doi: 10.1530/jrf.0.1020425.

LOSOS, GJ; IKEDE, B.O. Review of pathology of disease in domestic and laboratory animals caused by $T$. vivax, T. brucei, $T$. rhodesiense and $T$. gambiense. Journal of Chemical Information and Modeling. v.53, p.1689-99, 1972. Available from: $<\mathrm{https}: / /$ doi.org/10.1017/CBO9781107415324.004>. Accessed: Jan. 05, 2020. doi: $10.1177 / 030098587200901 \mathrm{~s} 01$.

MAGEZ, S., \& RADWANSKA, M. Trypanosomes and Trypanosomiasis, Parasites \& Vectors, 1-294, 2014. Available from: <https://doi.org/10.1007/978-3-7091-1556-5>. Accessed: Jan. 05, 2020. doi: 10.1007/978-3-7091-1556-5.

MENDOZA A., et al. Diagnóstico Clínico del Ovino. Journal of Chemical Information and Modeling. v.53, 2013. Available from: <https://doi.org/10.1017/CBO9781107415324.004>. Accessed: Jan. 05, 2020. doi: 0.1017/CBO9781107415324.004.

MOHAMMED, S., et al. Incidence and prevalence of tickborne haemoparasites infecting sheep and goats in Sennar state, Sudan. International Journal of Biology Research. v.3: p.173-77, 2018. Available from: <https://www.researchgate.net/ publication/327281786 Incidence and prevalence of tickborne_haemoparasites_infecting_sheep_and_goats_in_Sennar_ state Sudan>. Accessed: Jan. 05, 2020. doi: 10.7150/ijbs. 42965.

MORA SANCHEZ B.; CASTRO K. (2015). Infección por Trypanosoma sp. en ovinos sintomáticos en el Municipio de León, Nicaragua. Revista Científica de la UNAN-León. v.6, p.1-10, 2015. Available from: <http://revista.unanleon.edu.ni/index.php/ universitas/article/view/98/pdf 11>. Accessed: Jan. 05, 2020. doi: 10.22004/ag.econ.232902.

N'DJETCHI, M. K., et al. (2017). The study of Trypanosome species circulating in domestic animals in two human African 
trypanosomiasis foci of Côte d'Ivoire identifies pigs and cattle as potential reservoirs of Trypanosoma brucei gambiense. PloS Negl Trop Dis. v11, p.1-16, 2017. Available from: <https://www.ncbi. nlm.nih.gov/pmc/articles/PMC5662240/pdf/pntd.0005993.pdf> Accessed: Jan. 05, 2020. doi: 10.1371/journal.pntd.0005993.

NG'AYO, M. O., et al. (2005). Detection of trypanosomes in small ruminants and pigs in western Kenya: Important reservoirs in the epidemiology of sleeping sickness?. Kinetoplastid Biology and Disease. v.4, p.1-7, 2005. Available from: $<\mathrm{https}$ :// doi.org/10.1186/1475-9292-4-5>. Accessed: Jan. 05, 2020. doi: $10.1186 / 1475-9292-4-5$.

ONAH, D.N., et al. Haematological changes in sheep experimentally infected with Trypanosoma evansi. Parasitology Research. v.82, p.659-63, 1996. Available from: <https://doi. org/10.1007/s004360050181>. Accessed: Jan. 05, 2020. doi: $10.1007 / \mathrm{s} 004360050181$.

PARRA-GIMENEZ, N.; REYNA-BELLO, A. Parasitological, Hematological, and Immunological Response of Experimentally Infected Sheep with Venezuelan Isolates of Trypanosoma evansi, Trypanosoma equiperdum, and Trypanosoma vivax. Journal of Parasitology Research.2019. Available from: <https://doi. org/10.1155/2019/8528430>. Accessed: Jan. 05, 2020. doi: $10.1155 / 2019 / 8528430$
RENNEKER, S.; ABDO, JM.; BAKHEIT, MA.: SEITZER, U. Coinfección de ovejas con especies de Anaplasma, Theileria y Babesia en la región del Kurdistán, Iraq. Transboundary and Emerging Diseases. v.60 (2), p.113-118, 2013. doi: 10.1111/tbed.12148.

REYNA BELLO, A. First report and molecular identification of Trypanosoma vivax in cattle from Ecuador. 2017. Available from: $<\mathrm{https}: / /$ www.bibliotecasdelecuador.com/Record/oai:localhost:28000-3999>. Accessed: Jan. 05, 2020.

ROMERO O. (2015). Evaluación de la Condición Corporal y Edad de los ovinos. Instituto de Investigaciones Agropecuarias. v.79, 1-94, 2015. Available from: <http://biblioteca.inia.cl/medios/ biblioteca/informativos/NR40188.pdf $>$. Accessed: Jan. 05, 2020.

SEBELE, T., ZEWEDU, F., \& GETACHEW, A. G. (2015). A study of the prevalence of hemoparasites of ruminants in and around DebreZeit, Central Ethiopia.African Journal of Parasitology Research. v.2, p.66-71, 2015. Available from: <http://internationalscholarsjournals. org/download.php?id=252848229449121554.pdf\&type=application/ pdf\&op=1>. Accessed: Jan. 05, 2020.

TOMASSI, M., et al. Clinical Case Report: Trypanosomiasis in Sheep. Compendio de Ciencias Veterinarias. v.8, p.39-42, 2018. Available from: $<$ https://doi.org/10.18004/compend.cienc.vet.2018.08.01.39-42>. Accessed: Jan. 05, 2020.doi: 10.18004/compend.cienc.vet.2018.08.01.39-42. 